Do twórczych metod oddziaływań resocjalizacyjnych wobec młodzieży niedostosowanej społecznie odwołała się także mgr Renata Ilnicka, która przedstawiła obiecujące efekty zajęć socjoterapeutycznych na podstawie własnych badań.

Na konieczność planowania oddziaływań resocjalizacyjnych wobec nieletnich, działań dążących do podniesienia ich samooceny, redukujących poczucia niższości i kształtujących umiejętności wyrażania swoich uczuć zwróciła uwagę w swojej wypowiedzi również dr Anna Kieszkowska.

Pozostając w kręgu tematyki związanej z niedostosowaniem społecznym dr Joanna Cichla zaprezentowała strukturę i dynamikę przestępczości nieletnich.

Wnioski z Ogólnopolskiej Konferencji Naukowej „Opieka - Wychowanie - Resocjalizacja. Tradycja i problemy współczesne” zostały zaprezentowane i poddane dyskusji w drugim dniu obrad. Pozostaje mieć nadzieję, że staną się inspiracją do podejmowania decyzji i intelektualnym zapleczem rozwiązań praktycznych zmierzających do rozwoju i naprawy ludzkiego świata.

Danuta Apanel Anetta Jaworska

\title{
„Czasopiśmiennictwo XIX i XX wieku jako źródło do dziejów szkolnictwa, oświaty i edukacji”
}

Na powyższy temat debatowano w dniach 15-16 października 2009 r. w Centrum Szkoleniowo-Konferencyjnym Uniwersytetu Łódzkiego. Konferencja zorganizowana została przez Katedrę Historii Wychowania i Pedeutologii Wydziału Nauk o Wychowaniu Uniwersytetu Łódzkiego.

Celem konferencji było omówienie szczególnego rodzaju źródeł do dziejów szkolnictwa, oświaty i edukacji, jakimi są periodyki w szerokim tego słowa znaczeniu. Czasopisma są bowiem ważnym źródłem dla badania przeszłości edukacyjnej. Okazuje się, że w korzystaniu z periodyków jako źródeł uwzględniać należy nie tylko pisma stricte pedagogiczne, ale sięgać trzeba do wielu innych czasopism, po to, aby w sposób pełniejszy zaprezentować przeszłość oświatową.

Gości przywitał Przewodniczący Komitetu Organizacyjnego omawianego spotkania, Dziekan Wydziału Nauk o Wychowaniu - prof. dr hab. Grzegorz Michalski. Zwrócił on uwagę na to, że konferencja odbywa się w czasie 70. urodzin zmarłego przedwcześnie byłego Kierownika Zakładu Historii Wychowania UŁ, prof. Tadeusza Jałmużny, prosząc o uczczenie pamięci Zmarłego chwilą ciszy. Następnie głos zabrali: Prorektor UŁ prof. dr hab. Antoni Różalski oraz Prodziekan Wydziału Nauk o Wychowaniu UŁ - prof. dr hab. Danuta Urbaniak-Zając, witając serdecznie wszystkich zgromadzonych. 
Po części wstępnej, prof. G. Michalski zaprezentował krótki szkic problematyki konferencji. Wskazał na rozwój czasopiśmiennictwa na przestrzeni lat, zwracając uwagę na rolę czasopisma jako źródła historycznego.

Część plenarną obrad rozpoczął i prowadził prof. dr hab. Lech Mokrzecki. Obrady w tej części otworzył prof. dr hab. Kazimierz Puchowski z Uniwersytetu Gdańskiego, prezentując temat „Prasa oświeceniowa o modelu kształcenia elit”. Autor na podstawie zbadanych tytułów, m.in. „Kuriera Polskiego”, „Wiadomości Literackich”, „Wiadomości Warszawskich”, czy „Gazety Wileńskiej”, zaprezentował bogaty obraz tematyki edukacyjnej, jaka poruszana była na łamach pism (m.in. krytyka szkoły, poczynania reformatorskie w zakresie edukacji, promocja, rywalizacja, upowszechniany wizerunek ówczesnych władz, autonomia edukacyjna poszczególnych zakonów).

Ważny obszar poszukiwań badawczych poruszył prof. dr hab. Sławomir Sztobryn z Uniwersytetu Łódzkiego, ukazując „Problematykę historiografii pedagogicznej w czasopismach tradycyjnych i elektronicznych”. Zwrócił uwagę na kontrowersje wokół pojawiających się obecnie możliwości dygitalizowania czy cyfrowania tekstów dostępnych do tej pory w wersji drukowanej. Dokonując przeglądu czasopism naukowych oraz ich stopnia zaangażowania w dygitalizację czy cyfryzację, autor wyraził nadzieję na upowszechnienie się wiedzy i dokonań badawczych, prezentowanych dotychczas na łamach czasopism drukowanych, w formie elektronicznej.

Prof. dr hab. Władysława Szulakiewicz z Uniwersytetu im. Mikołaja Kopernika w Toruniu, w referacie pt. „Czasopisma historyczno-oświatowe źródłem informacji o polskiej historii wychowania", ukazała funkcje, jakie czasopisma naukowe spełniają. Przedstawiła ważne zadania różnych działów periodyków, jak m.in. działu recenzji, działu not, czy działu bibliografii. Prof. Szulakiewicz, dokonując przeglądu czasopism wskazała na ich rozwój, ale zwróciła też uwagę na problemy, którym należy zapobiegać, jak brak dbałości niektórych pism o ciągłość wydawniczą.

Konferencja w drugiej części odbywała się w trzech sekcjach tematycznych: „Czasopiśmiennictwo w czasach zaborów”, „Czasopiśmiennictwo w Drugiej Rzeczypospolitej” oraz „Czasopiśmiennictwo po 1945 roku”.

Obradom sekcji „Czasopiśmiennictwo w czasach zaborów” przewodniczyli prof. dr hab. Wiesław Jamrożek (Uniwersytet im. A. Mickiewicza w Poznaniu) i prof. dr hab. Kazimierz Puchowski (Uniwersytet Gdański).

Pierwszy referat wygłosił dr Marcin Wasilewski (Uniwersytet Łódzki), przedstawiając problematykę helleńską w artykułach naukowych i popularnonaukowych Stanisława Schneidra. Zwrócił uwagę na konieczność powrotu do poglądów mało znanego lwowskiego badacza. Z kolei dr Krzysztof Ratajczak (Uniwersytet im. A. Mickiewicza w Poznaniu) zreferował dzieje średniowiecznego szkolnictwa w naukowych czasopismach polskich XIX i początków XX w. Dr Magdalena Dąbrowska (Uniwersytet Warszawski), z punktu widzenia literaturoznawcy, dokonała analizy tekstów w czasopiśmie „Patrijot” (1804) Władimira Izmajłowa, wskazując trzy główne pola tematyczne: treści dla wychowawcy, dla dzieci i dla młodzieży. W dwóch kolejnych wystąpieniach podjęto tematykę czasopism adresowanych do dzieci. Dr Joanna Dąbrowska (Uniwersytet w Białymstoku) scharakteryzowała pierwszy polski periodyk dla dzieci i młodzieży - „Rozrywki dla 
dzieci”, przedstawiając poszczególne działy czasopisma. Mgr Anna Mamulska (Państwowa Wyższa Szkoła Zawodowa im. J. A. Komeńskiego w Lesznie) omówiła, odwołując się do wielu interesujących fragmentów źródłowych, różne aspekty wychowania moralnego w XIX-wiecznych czasopismach dla dzieci zaboru pruskiego. Kwestię problemów oświaty i wychowania na łamach „Biblioteki Warszawskiej” podjęła dr Ewa Witkowska-Urban (Uniwersytet Łódzki). Wskazała na główne zagadnienia tego czasopisma: wychowanie moralne, wychowanie i edukację kobiet, rozwój nauk ścisłych. Natomiast analizę galicyjskiej „Krytyki” jako źródła do dziejów edukacji podjął prof. dr hab. Wiesław Jamrożek (Uniwersytet im. A. Mickiewicza w Poznaniu). Kolejne trzy wystąpienia dotyczyły problemów szeroko rozumianej higieny i zdrowia. Dr Aneta Bołdyrew (Uniwersytet Humanistyczno-Przyrodniczy im. J. Kochanowskiego w Kielcach) zaprezentowała problematykę zdrowia i higieny młodzieży szkolnej w Królestwie Polskim na przełomie XIX i XX w. na łamach czasopism medycznych, zwracając uwagę na kwestie zawarte w periodykach, m.in. na stan sanitarny w szkołach, stan zdrowia dzieci, dziecięce choroby zakaźne, przeciążenie nauką, alkoholizm wśród dzieci. Kontynuując tematykę zdrowia, dr Małgorzata Stawiak-Ososińska (Uniwersytet Humanistyczno-Przyrodniczy im. J. Kochanowskiego w Kielcach) omówiła zagadnienia kształcenia akuszerek na ziemiach polskich w XIX i na początku XX w. w pierwszych czasopismach dla położnych. Natomiast dr Elżbieta Dolata (Uniwersytet Rzeszowski) scharakteryzowała poglądy na problemy higieny szkolnej zawarte w czasopismach galicyjskich. Sprawy wychowania i edukacji dziewcząt w XIX w. poruszane na łamach poznańskiego „Dziennika Domowego" zaprezentowała mgr Kinga Jackowska (Muzeum Warmii i Mazur w Olsztynie). Zagadnienie rozwoju i funkcjonowania szkolnictwa elementarnego w Łodzi w zaborze rosyjskim podejmowane na łamach łódzkich periodyków, przedstawił mgr Piotr Kędzia (Uniwersytet Łódzki). Natomiast problematykę rozwoju polskich gimnazjów w pierwszych dziesięcioleciach XX w., zawartą w czasopiśmie „Muzeum” scharakteryzowała dr Teresa Gumuła (Uniwersytet Humanistyczno-Przyrodniczy im. J. Kochanowskiego w Kielcach). Na zakończenie obrad tej sekcji dr Izabela Krasińska (Uniwersytet Humanistyczno-Przyrodniczy im. J. Kochanowskiego w Kielcach) omówiła problem wychowania do życia w trzeźwości dzieci i młodzieży, poruszany na łamach polskiej prasy abstynenckiej z lat 1902-1914.

Sekcji „Czasopiśmiennictwo w Drugiej Rzeczypospolitej” przewodniczył prof. dr hab. Roman Tomaszewski (Akademia Pomorska w Słupsku), który zaprezentował problematykę wychowania w czasopismach II RP. Dr Jan Ryś (Uniwersytet Pedagogiczny w Krakowie) poruszył problematykę wychowania i oświaty na łamach prasy wojskowej w pierwszych latach niepodległości (1918-1921). Komunikat z badań na temat „Prasa mariawicka jako źródło do badań nad praktyką i ideologią oświatową mariawitów (do roku 1935)" przedstawił mgr Tomasz Mames (Akademia Wychowania Fizycznego w Krakowie/Uniwersytet Jagielloński). Dr Izabela Stelmasiak (Akademia Pomorska w Słupsku) zaprezentowała wystąpienie na temat „Czasopismo 'Straży Przedniej' 'W Młodych Oczach' i jego otoczenie”. Problematykę dotyczącą edukacji obywatelskiej na łamach czasopisma „Oświata i Wychowanie” ukazała prof. dr hab. Wiesława Leżańska (Uniwersytet Łódzki). Dr Aleksandra Lubczyńska (Uniwersytet Humanistyczno- 
-Przyrodniczy im. J. Kochanowskiego w Kielcach) scharakteryzowała edukację regionalną i krajoznawczą na łamach „Ziemi” w latach 1910-1939. „Udział czasopisma „Społem” w propagowaniu wychowania spółdzielczego dzieci i młodzieży w II Rzeczypospolitej (1918-1939) został omówiony przez dr Elżbietę Magierę (Uniwersytet Szczeciński). Dr Kamilla Łozowska-Marcinkowska (Uniwersytet Medyczny im. K. Marcinkowskiego w Poznaniu) zapoznała słuchaczy z problematyką poradnictwa domowego przedstawianą na łamach wybranych czasopism kobiecych w dwudziestoleciu międzywojennym. „Problemy opieki i wychowania w periodyku dla kobiet 'Moja Przyjaciółka' (1934-1939)" zaprezentowane zostały przez prof. dr. hab. Grzegorza Michalskiego (Uniwersytet Łódzki). Dr Iwonna Michalska (Uniwersytet Łódzki) dokonała natomiast analizy roli kobiety w rodzinie na łamach „Pani Domu” (1932-1939). Analizę zawartości czasopism religijnych dla młodzieży gimnazjalnej w II RP przeprowadził dr Andrzej Mazan (Uniwersytet Kardynała Stefana Wyszyńskiego w Warszawie). Mgr Katarzyna Ossowska (Uniwersytet Humanistyczno-Przyrodniczy im. J. Kochanowskiego w Kielcach), analizując wybrane czasopisma, ukazała ich edukacyjny przekaz dla młodzieży harcerskiej w latach 1911-1939. „Główne funkcje wychowawcze na łamach czasopisma dla młodzieży 'Iskry' (1923-1939)” przedstawione zostały przez mgr Kingę Szymczak (Uniwersytet Łódzki).

Sekcji obradującej pod hasłem „Czasopiśmiennictwo po 1945 roku” przewodniczyły prof. dr hab. Alicja Kicowska oraz prof. dr hab. Eleonora Sapia-Drewniak.

Obrady w tej sekcji otwarte zostały prezentacją mgr. Marcina Lutomierskiego (Uniwersytet M. Kopernika w Toruniu) pt. „Londyńskie 'Wiadomości’ (1946-1956) jako źródło do dziejów emigracyjnego szkolnictwa, oświaty i edukacji”. Dr Danuta Apanel (Akademia Pomorska w Słupsku) w pracy pt. „Pismo 'Problemy Opiekuńczo-Wychowawcze' w rozwoju polskiej pedagogiki opiekuńczej” dokonała przeglądu periodyku od momentu jego powstania (1961 r.), przedstawiając ewolucję pisma w zakresie prezentacji treści dotyczących niesienia pomocy placówkom opiekuńczo-wychowawczym, ale też szkołom. Próbę charakterystyki niezależnych pism młodzieżowych redagowanych i powielanych nielegalnie w latach 80., głównie przez młodzież szkół średnich podjęła dr Justyna Gulczyńska (Uniwersytet im. A. Mickiewicza w Poznaniu). Autorka ukazała różne obszary tematyczne, prezentowane na łamach tych pism. Referat uzupełniony został prezentacją multimedialną wybranych (zeskanowanych) czasopism. Prof. dr hab. Irena Szewczyk-Kowalewska (Uniwersytet Łódzki) rozważała zagadnienie edukacji kulturalnej dziecka w latach 90. na łamach periodyku „Edukacja i Dialog”. Ważne zagadnienie w dzisiejszej szkole dotyczące systemu oceniania dzieci w klasach I-III podjął, w pracy pt. „Rozważania nad systemem oceniania w klasach I-III szkoły podstawowej na łamach czasopisma dla nauczycieli ‘Życie Szkoły’”, mgr Michał Kowalewski (Uniwersytet Łódzki). Ukazał on trwającą nieustannie w periodyku dyskusję pomiędzy zwolennikami a przeciwnikami oceniania. Zwrócił uwagę na „kult obliczania”, jaki panuje w szkole. Dr Agnieszka Wałęga (Uniwersytet M. Kopernika w Toruniu), w referacie pt. „Wychowanie wobec tradycji i wyzwań współczesności. Problematyka pedagogiczna na łamach 'Horyzontów Wychowania”, dokonała wszechstronnej analizy pisma. „Edukacja międzykulturowa w obrazach. Siła humanistycznego przekazu emanująca z ,National 
Geographic"”, to temat referatu dr Anety Rogalskiej-Marasińskiej (Uniwersytet Łódzki). Autorka przez nakreślenie obszarów pedagogicznych edukacji międzykulturowej na łamach prezentowanych w piśmie zdjęć, wskazała, jak ważnymi i wymownymi mogą być w swej treści obrazy. Dr Anna Haratyk (Uniwersytet Wrocławski) przedstawiła rolę współczesnych pism popularnonaukowych jako źródeł wiedzy historycznej i kulturowej, odwołując się do czasopisma regionalnego „Tatry”, ukazującego się na Podhalu od lat 90. XIX w.

Prof. dr hab. Alicja Kicowska (Uniwersytet Warmińsko-Mazurski w Olsztynie) zaprezentowała rolę czasopisma „Wiadomości Mazurskie” w rozwoju szkolnictwa rolniczego do roku 1956. Autorka wykazała indoktrynacyjny wpływ czasopisma sterowanego przez ówczesną władzę, gdzie m.in. dominowała tematyka szkół rolniczych przygotowujących do pracy w dużych gospodarstwach rolnych, jak PGR, pomijając zagadnienia indywidualnego rolnictwa (co łączyło się z ówczesną propagandą kolektywizacji rolnictwa). Kreację rzeczywistości społeczno-politycznej na łamach „Sztandaru Młodych” przed 1956 r. i jego propagandową rolę w kształtowaniu światopoglądu młodzieży szkolnej zaprezentowała dr Joanna Król (Uniwersytet Szczeciński). Dr Maria Radziszewska (Uniwersytet Warmińsko-Mazurskiego w Olsztynie) ukazała zamieszczane na łamach olsztyńskiej prasy lokalnej (w latach 1945-1989) problemy szkolnictwa Warmii i Mazur. Problematyka edukacji w czasopismach drugiego obiegu wydawanych w latach 19801989 była przedmiotem rozważań dr. Ryszarda Ślęczki (Uniwersytet Pedagogiczny w Krakowie).

Konferencja łódzka w sposób zasadniczy wykazała, jak ważnym źródłem dla badania przeszłości edukacyjnej są periodyki, których bogactwo i wszechstronność ukazuje jej wieloaspektowy obraz.

Justyna Gulczyńska

Katarzyna Kabacińska

\section{Sprawozdanie z konferencji „Od grzechotki do klocków Lego - dawne i współczesne zabawki dziecięce" 7-8 grudnia 2009 Kielce}

W dniach 7-8 grudnia 2009 r. w ramach obchodów 30-lecia powstania Muzeum Zabawek i Zabawy w Kielcach, w pięknym i nowym budynku Muzeum, odbyła się konferencja: „Od grzechotki do klocków Lego - dawne i współczesne zabawki dziecięce”. Organizatorami sesji byli: Wydział Studiów Edukacyjnych Uniwersytetu im. Adama Mickiewicza w Poznaniu, kieleckie Muzeum Zabawek i Zabawy oraz Uniwersytet Hu- 